Archiv für die gesamte Virusforschung 31, 352-364 (1970)

(C) by Springer-Verlag 1970

\title{
Antigenic Relationships amongst Coronaviruses
}

\author{
$\mathrm{By}$ \\ A. F. Bradburne \\ Common Cold Unit, Harvard Hospital, Coombe Road, \\ Salisbury, Wiltshire, England \\ With 3 Figures \\ Received February 6, 1970
}

\begin{abstract}
Summary
Several serological interrelationships between various members of the coronavirus group have been revealed in neutralization, complement fixation, and geldiffusion tests, using human and hyperimmune animal sera. Several members of this group of human and animal pathogens are shown to cross-react in one or more type of test, but one member, avian infectious bronchitis virus, was shown to be unrelated. Mouse hepatitis virus $\left(\mathrm{MHV}_{3}\right)$ was found to be antigenically related to a number of human types of coronavirus. Difficulties were encountered in the investigation of paired human sera in demonstrating the specificity of antibody rises, placing doubt on the values of some serological studies. The significance of these interrelationships is discussed in the light of other investigations.
\end{abstract}

\section{Introduction}

A new group of viruses has been isolated from cases of upper respiratory disease in man. These viruses have a common morphology with that of the viruses of avian infectious bronchitis (BERRY et al., 1964) and mouse hepatitis (TYRRELt, and ArmeIda, 1967). These agents are ether and acid-labile, probably contain RNA and are composed of pleomorphic bodies $80-150 \mathrm{~m} \mu$ in diameter which, by negative staining, are seen to be surrounded by a fringe of club-shaped projections about $15 \mathrm{~m} \mu$ deep. The resemblance of this fringe to a crown has resulted. in the name "Coronaviruses" being proposed for the group (NATURE, 1968).

Many isolations have been made of avian infectious bronchitis (AIB) and serologically these fall into several serological types on the basis of neutralization tests (EsToLA, 1966). There are at least three serological types of mouse hepatitis virus (MHV) (GLEDHWL, 1961). Some of the isolations of coronaviruses from man have been made in human embryo diploid lung cell strains (HDCS). These isolates have all cross-reacted completely in neutralization tests with antisera to the prototype strain 229 $\mathrm{E}$ isolated by Hamre in 1962 (Hamre and Procknow, 1966). Other viruses of this group which are pathogenic to man have been isolated in 
organ cultures of human embryo nasal and tracheal epithelium. These isolates comprise at least three, and probably more, distinct serological types as judged by neutralization tests using convalescent human sera (BRADBURNE and TYRRELL, 1969; McIntost et al., 1969).

This work describes the detection of several serological relationships be* tween the viruses isolated from man, and those of mouse hepatitis and avian infectious bronchitis. The majority of these results were obtained before similar studies were reported by McINTosh et al. (1969); furthermore, different reagents were used and several extra cross-reactions were detected.

\section{Materials and Methods}

\subsection{Tissue Cultures}

These were all propagated in this laboratory. Roller tube neutralization tests were performed in monolayer cultures of human embryo diploid lung cells (HDCS). These were either a strain derived at the Unit, or the WI-38 cell strain.

Plaque neutralization tests were made using monolayers of $\mathrm{L} 132$ cells in $50 \mathrm{~mm}$ plastic Petri dishes (Sterilin). The $\mathrm{L} 132$ cell line is a continuous epitheloid cell line which was derived from human embryo lung (DAvIs, 1960) and has been shown to be sensitive to several respiratory viruses, including 4 strains of coronaviruses (BRADBURNE, 1969). All cultures were maintained at $33^{\circ} \mathrm{C}$ after inoculation.

\subsection{Viruses}

The $229 \mathrm{E}$ isolate of Dr. D. Hamre was propagated in WI-38 and L 132 cell cultures. The $\mathrm{OC} 38$ and $\mathrm{OC} 43$ virus strains had been isolated by MeIntosh in human tracheal organ cultures (McINTosh et al., 1967) and had been adapted to infect suckling mice by the intracerebral route (McINTosh, BECKER and CHANock, 1967). The virus was propagated by intracerebral inoculation of 2 to 5 day-old mice (Porton Albino strain). Mouse hepatitis virus (strain $\mathrm{MHV}_{3}$ ) was obtained from the late Dr. A. Gledhill. It was cultivated in weanling mice, in the brains of suckling mice or in primary mouse macrophage cultures obtained by peritoneal lavage after stimulation of the animals with starch broth. B 814 und LP viruses (TrRReLI and BrnoE, 1965; TrrRent, Bynoe and HoorN, 1968) were used as pools prepared from infeeted L 132 cells. Avian infectious bronchitis virus (Beaudette strain) was obtained from Mr. R. Henry and was used as infectious suckling mouse brain, or allantoic fluid obtained after the inoculation of 10-day embryonated eggs.

\subsection{Antisera}

Volunteers were inoculated with coronavirus isolates which had been made from man. The inocula used were either infectious organ culture fluids, or nasal washings taken in broth saline. Paired serum samples were taken from these persons, one before inoculation, and one about three weeks later. Hyperimmune animal sera were raised either in rabbits, by intramuscular injection with incomplete Freund's adjuvant followed by intravenous challenge with the same antigen, or in mice by the production of immune ascitic fluid by the method of Sommerville (SomMERviLte, 1967).

Wherever possible, the mice were immunised with suspensions of infected mouse brain to avoid the production of anti-tissue antibody. If this was not possible then animals were inoculated with tissue culture pools of virus prepared from monolayers which had been washed free of serum and then infected. When cytopathic effects appeared in the cultures they were frozen and thawed, concentrated 50 -fold by dialysis against polyethylene glycol 'PEG 6000', and clarified by centrifugation. Immune mouse sera against MHV ${ }_{1}$ and $\mathrm{MHV}_{3}$ were prepared by inoculating weanling mice with $0.5-2 \mathrm{MLD}_{50}$ of virus; survivors were exsanguinated four weeks later. The Porton albino mice used had no antibody against $\mathrm{MHV}_{1}$ or $\mathrm{MHV}_{3}$ prior to immunization and were highly susceptible to both pathogens. 
Sera were inactivated at $56^{\circ} \mathrm{C}$ for 30 minutes before neutralization tests and complement fixation tests with hyperimmune aseitic fluids. Human and rabbit sera, when used in complement fixation tests, were inactivated at $65^{\circ} \mathrm{C}$ for 30 minutes to remove any anti-complementary activity.

\subsection{Neutralization Tests}

Preparations of virus of known titre were diluted in a special diluent containing $50 \%$ nutrient broth and $50 \%$ Hanks' BSS and a final $0.1 \%$ bovine plasma albumin. The diluted suspensions were centrifuged at $3000 \mathrm{~g}$ for 20 minutes and stored at $-70^{\circ} \mathrm{C}$. For tissue culture neutralization tests approximately $200 \mathrm{TCD}_{50} / \mathrm{ml}$ (in HDCS) or p.f.u./ml (in L 132 cells) of the appropriate virus were mixed with equal volumes of dilutions of the inactivated sera. These were maintained at room tem. perature for 2 hours and then $0.2 \mathrm{ml}$ aliquots were inoculated into roller tube cultures of HDCS cells (WI-38). The tubes were examined for cytopathic effects at 5 and 7 days.

Plaque reduction tests were performed in monolayers of L 132 cells in $50 \mathrm{~mm}$ Petri dishes. These were inoculated with $0.2 \mathrm{ml}$ of the virus-serum mixture, absorbed for 3 hours at $30^{\circ} \mathrm{C}$, and then overlaid with a medium deseribed by BRADBURNE and TrRrell (1969). Plaques were counted after 6 days incubation at $33^{\circ} \mathrm{C}$.

Neutralization tests with $\mathrm{MHV}_{3}$ virus were performed in a similar manner but the virus was inoculated into cultures of primary mouse peritoneal macrophages. For infectious bronchitis virus (IBV Beaudette) the test system used was primary chick embryo kidney prepared by the method of Estola (1966). Neutralization tests with the OC 43 virus were carried out in suckling mice by intracerebral inoculations of the virus-serum mixtures.

For each virus-serum mixture 3 plates of 3 tubes were used in tissue culture neutralization tests, and at least 5 mice in mouse neutralization tests. Neutralization endpoints in plaque reduction tests were determined as the dilution of serum which would just produce a $50 \%$ reduction in the control plaque count. For tube neutralization tests, end-points were determined by the method of REED and MvencH (1938).

\subsection{Haemagglutination-Inhibition Tests}

KAYE and DOWDLE (1969) have reported that high-titre preparations of $O C 43$ and $0 \mathrm{C} 38$-infected mouse brain agglutinate human ' 0 ', rat, mouse and chicken red cells at various temperatures. This was confirmed using antigens made by homogenising infected mouse brain at a $10 \%$ concentration in phosphate buffered saline $(\mathrm{pH} \mathrm{7.1)}$ and clarifying by centrifugation at $3000 \mathrm{~g}$ for 10 minutes. Although rat and mouse cells were 4 to 8 -fold more sensitive in the haemagglutination test, they often did not settle satisfactorily and therefore $\mathbf{0 . 5 \%}$ chicken erythrocytes were used. In haemagglutination-inhibition ( $\mathrm{HI}$ ) tests 4 agglutinating doses of virus were used and the test was performed in microtitre plates using $0.025 \mathrm{ml}$ drop-volumes. Antisera were inactivated at $56^{\circ} \mathrm{C}$ for 30 minutes and reacted with virus for 1 hour at room temperature. Chicken erythrocytes were then added and allowed to settle for a further 50 minutes; the tests were read immediately.

Attempts were made to detect haemagglutination by other coronavirus antigens, including extracts of mouse brain infected with $\mathrm{MHV}_{1}, \mathrm{MHV}_{3}$ and $\mathrm{AIB}$ viruses. These were all unsuccessful.

\subsection{Complement Fixation Tests}

These were carried out by the mierotitre method of Takatsy ( $S_{E V E R}, 1962$ ) using $0.025 \mathrm{ml}$ volumes. Specific fixation was only revealed when low doses of complement were used and in most tests between 1.5 and $1.75100 \%$ haemolytic units of complement were employed, using overnight fixation at $+4^{\circ} \mathrm{C}$. The complement dose was determined by preparing close-range dilutions of the solution of complement in triplicate and estimating these in parallel with the rest of the test.

Where possible (for $\mathrm{MHV}_{3}, \mathrm{AIB}, \mathrm{OC} 43$ ) $20 \%$ suspensions of infected suckling mouse brain were used as CF antigens. These were clarified by centrifugation at $3000 \mathrm{~g}$. Antigens for those coronaviruses which could only be cultivated in tissue culture, 
were partially purified by gel filtration. Tissue culture pools of virus, prepared in se. rum-free medium were homogenised, concentrated 10-fold by dialysis against $P E G 6000$, clarified by centrifugation, and filtered on a column of Sephadex G-200 gel. Material which had been excluded by the gel was concentrated by dialysis and frozen at $-20^{\circ} \mathrm{C}$ until use.

\subsection{Gel-diffusion Tests}

These were done by the micro-method of Crowle using 1\% Agar No. 1 (Oxoid) in phosphate buffered saline ( $\mathrm{pH} 7.1$ ) containing $1 \%$ phenol and $0.1 \%$ sodium azide. Tests were set up on microscope slides using "Perspex" templates. The reagents were allowed to diffuse for 48-96 hours at room temperature. Then the templates were removed and the slides were washed overnight in PBS and photographed by darkground illumination.

\section{Results}

\subsection{Neutralization Tests}

Paired sera taken from volunteers who had been infected with the LP or the $229 \mathrm{E}$ virus showed significant rises in neutralizing antibody against both viruses by both roller-tube and plaque-reduction tests. An antibody response to the

Fig. 1. The correlation between antibody rises to $229 \mathrm{E}$ and to $L P$ viruses in paired sera taken from volunteers showing rising antibody titres to the virus with which they were infected. Volunteers given - $229 \mathrm{E},-\cdots . \mathrm{L} P$, Preserum O, Postserum

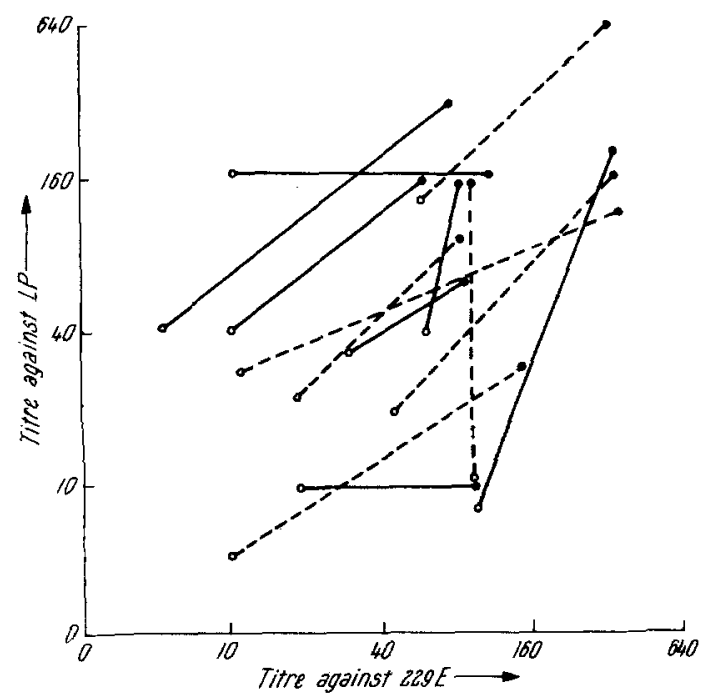

homologous virus was usually accompanied by a rise in titre to the heterologous virus (see Fig. 1). Antibody rises detected after infection of volunteers with the B814 virus or with OC43 virus only related to the homologous virus. These results are expressed in Table 1 . It should be emphasized that only a limited number of sera were available from volunteers with B8I4 and OC43 infections and were not screened for antibody rises against the infecting strain because of difficulities in manipulating the viruses. Five and 6 pairs of sera showing greater than 4 -fold rises in antibody titre to the $229 \mathrm{E}$ and LP viruses, respectively, were also tested against $\mathrm{MHV}_{3}$ and $\mathrm{AIB}$; no rises in neutralizing antibody directed against $\mathrm{MHV}_{3}$ were detected and none of the sera developed any antibody to AIB even at a serum dilution of 1 in 5 .

The immune response detected against $229 \mathrm{E}$ and LP viruses in these volunteer sera were not necessarily greatest against the homologous virus as shown in 
Fig. 1. One cannot be sure whether antibody rises detected in human volunteers are the result of the virus infection given experimentally. They may be influenced by previous infections with related viruses. To clarify this situation, hyperimmune ascitic fluids from mice exposed to only one coronavirus were studied. Where possible, plaque reduction tests were employed as these had proved to be a more sensitive assay than the neutralization of cytopathic effects in roller tube cultures. The results are shown in Table 2.

Sera directed against LP virus neutralized $229 \mathrm{E}$ but antiserum to $229 \mathrm{E}$ virus almost failed to neutralize LP in tube neutralization tests. Mouse ascites stimulated by $\mathrm{OC} 43$ virus neutralized the $229 \mathrm{E}$ virus, but to a 10 - to 20 -fold lower dilution than OC43. Ascitic fluid from mice hyperimmunized with $229 \mathrm{E}$ virus did not neutralize the effects of $0 \mathrm{C} 43$ virus in suckling mice, but it neutralized LP plaques repeatedly to between $1 / 5$ th and $1 / 10$ th of the homologous titre. Hyperimmune ascitic fluids against $\mathrm{B} 814, \mathrm{MHV}_{3}$ and $\mathrm{ATB}$ (Beaudette) viruses did not neutralize OC43, $229 \mathrm{E}$ or LP viruses.

Table 1. Rising Neutralizing Antibody Titres to 229E and LP Viruses after Infection of Volunteers with Various Coronaviruses

\begin{tabular}{lccl}
\hline $\begin{array}{l}\text { Volunteers } \\
\text { given: }\end{array}$ & $\begin{array}{l}\text { No, of sera showing 4-fold } \\
\text { or greater rises against: }\end{array}$ & \multirow{2}{*}{$\begin{array}{l}\text { Number tested } \\
\text { (pairs) }\end{array}$} \\
\cline { 2 - 3 } & $229 \mathrm{E}$ & LP & \\
\hline $229 \mathrm{E}^{1}$ & 18 & 16 & 18 \\
$\mathrm{LP}^{1}$ & 20 & 20 & 20 \\
$\mathrm{OC} \mathrm{43}^{2}$ & 1 & 1 & 14 \\
$\mathrm{~B} 814^{2}$ & 0 & 0 & 10 \\
\hline
\end{tabular}

Of 14 paired sera from volunteers given OC43 virus, 5 had 4 -fold or greater rises in HI antibody titres to OC 43 .

Of 10 paired sera from volunteers given B 814 virus 3 had 4.-fold rises in neutralizing antibody titres to $\mathrm{B} 814$.

1 Sera selected because they showed significant rises to the homologous virus.

2 Sera selected from volunteers with colds.

The cross reactions were further confirmed by performing kinetic neutralization tests and determining the neutralization constants $(\mathrm{k})$ for each hyperimmune serum (diluted and inactivated 1 in 5 in saline) against LP and $229 \mathrm{E}$ viruses. There was only a small non-neutralizable fraction $(0.01-0.5 \%)$, of virus. The " $\mathrm{k}$ " values indicate that an antiserum to LP virus neutralizes LP and $229 \mathrm{E}$ at roughly the same rate, while antisera against the $229 \mathrm{E}$ virus neutralize LP less rapidly than $229 \mathrm{E}$. These results (Table 3 ) are thus very similar to previous tests.

The effects of complement on the plaque-reduction assay for the titration of antisera to the $229 \mathrm{E}$ and $\mathrm{LP}$ viruses were investigated as complement can have a marked effect on the neutralization of some enveloped viruses. Virus-serum mixtures were made in a diluent containing a final $25 \%$ of fresh rabbit serum. This diluent had no inhibitory effect on the viruses during the two-hour reaction period, as compared with dilutions made in a medium containing $25 \%$ heated rabbit serum. Complement was found neither to increase nor decrease the titres 
of antisera obtained against $229 \mathrm{E}$ and LP viruses in its absence. Furthermore, heterologous reactions were no more prominent than in the absence of complement.

Various anti-human sera were tested against these two viruses in the same system, as anti-host antisera have been shown to neutralise infectious bronchitis virus (BERRY and Almeida, 1968). Of 5 such sera tested, only one serum had any activity. This serum had been prepared in rabbits by the method already described. The antigens used for intramuscular injection were uninfected HDCS lung cells, and the intravenous injection was of an extract of normal human em. bryo lung. $229 \mathrm{E}$ was neutralised, but only when complement (rabbit serum) was present; LP was unaffected. The titre against $229 \mathrm{E}$ was 10 ; the cytotoxic titre to L 132 cells was 1 in 3 and the agglutinin titre for human erythrocytes was 2560 .

Table 2. Reciprocal Neutralization Titres of Antisera Directed against Various Coronaviruses

\begin{tabular}{|c|c|c|c|c|c|c|}
\hline \multirow{2}{*}{$\begin{array}{l}\text { Serum } \\
\text { against }\end{array}$} & \multicolumn{6}{|c|}{ Virus used in neutralization test } \\
\hline & $229 \mathrm{E}(\mathrm{PR})$ & $\mathrm{LP}(\mathrm{PR})$ & B 814 & $\mathrm{OC} 43(\mathrm{SM})$ & $\mathrm{MHV}_{3}(\mathrm{SM})$ & AIB (PR) \\
\hline $229 \mathrm{E}$ & 1600 & 80 & 5 & 5 & 5 & 5 \\
\hline LP & 10240 & 5120 & 5 & 5 & 5 & 5 \\
\hline B 814 & $\mathbf{5}$ & 5 & 640 & $\mathbf{5}$ & 5 & 5 \\
\hline $\mathrm{OC} 43$ & 160 & 5 & ND & 5120 & 5 & $\mathbf{5}$ \\
\hline MHV & 5 & 5 & ND & 5 & 1000 & 5 \\
\hline AIB & 5 & $\mathbf{5}$ & $\mathrm{ND}$ & 5 & 5 & 40 \\
\hline
\end{tabular}

$\mathrm{PR}=50 \%$ plaque reduction titre. $\mathrm{SM}=50 \%$ end-point titre in suckling mice. All tests used between 20 and 100 infectious units of virus.

\subsection{Haemagglutination Inhibition}

KAYE and DowDJE (1969) report that OC38 and OC43 mouse-brain antigens react with polyvalent antiserum to mouse hepatitis virus in the $\mathrm{HI}$ test. This cross reaction has been confirmed in these studies when mouse antisera to mouse hepatitis viruses $\mathrm{MHV}_{1}$ and $\mathrm{MHV}_{3}$ viruses were tested by HI; these had HI titres of 40 and 10, respectively. These sera both had titres of greater than 5000 in mouse neutralization tests. Hyperimmune antisera to other coronaviruses failed to give any reaction at dilutions of 1 in 2.5 or greater.

Paired sera which had been taken from volunteers before and after infection with various coronaviruses, except $\mathrm{OC} 38$ and $\mathrm{OC} 43$, were tested by HI against OC43. Of 70 such sera $10(14 \%)$ had 4 -fold or greater rises by HI.

\subsection{Complement Fixation Tests}

At an early stage in the investigation it was found that the results of complement fixation tests using coronavirus antigens were seldom constant or repeatable. This non-reproducibility has been reported by others (McINTosh et al., 1969). The titres of the antisera used were found to be exceptionally dependent upon the exact quantity of complement used during the overnight fixation. Using the standard quantity of complement (two haemolytic units) only high 
titre hyperimmune sera and potent antigens gave complete fixation. Using lower doses of complement the titres of some, but not all, sera increased considerably. Therefore all the tests quoted have been repeated to confirm the results, with the dose of complement usually kept at 1.75 units.

The dependence of such tests on the quantity of complement used was demonstrated by using a single antigen $\left(\mathrm{MHV}_{3}\right.$-infected mouse brain) with five different antisera at various dilutions of complement. The results of this are shown in Fig. 2. It can be seen that, apart from the serum resulting from a normal infection with $\mathrm{MHV}_{3}$, the sera do not have a uniform response over the complement range of 2 to 1.25 units and show maxima and minima in their reactions. This variation in complement-fixing equivalence is reproducible in terms of the maxima and minima shown but not in the actual titres obtained, probably because of the difficulty in the exact determination of the dose of complement. At about 1.5 units of complement, most of the sera are showing their maximum reactivity.

Table 3. Neutralization Constants $\left(23^{\circ} \mathrm{C}\right)$ for Hyperimmune Anti-coronavirus Antisera against $229 \mathrm{E}$ and $L P$ Viruses

\begin{tabular}{|c|c|c|}
\hline \multirow{2}{*}{$\begin{array}{l}\text { Hyperimmune } \\
\text { serum used. }\end{array}$} & \multicolumn{2}{|c|}{ Virus used } \\
\hline & $229 \mathrm{E}$ & LP \\
\hline Anti-229E & 5.75 & 0.28 \\
\hline Anti-LP & 7.22 & 4.60 \\
\hline Anti-B 814 & 0.07 & 0.08 \\
\hline Anti-0C43 (1) & 0.83 & 0.05 \\
\hline (2) & 0.14 & 0.05 \\
\hline Anti-MHV & 0.03 & 0.05 \\
\hline Anti-AIB & 0.01 & 0.05 \\
\hline
\end{tabular}

However, this dose of complement is lower than the optimum for reactions with LP and $229 \mathrm{E}$ antigens, which is about 1.8 units; for $\mathrm{OC} 43$ the optimum is about 1.65 units. Thus it is very difficult to use a number of coronavirus antigens with a single dose of complement. So, although tedious, the best results were obtained when three-dimensional complement fixation tests were employed.

Using crude tissue culture fluids as antigens, very few volunteer convalescent sera showed detectable levels of complement fixation. Therefore tissue culture fluids were concentrated 10 - to 20 -fold by dialysis, but the resulting fluids were often anti-complementary. It was found that the anti-complementary activity was removed by filtration on "Sephadex" G-200 gel, as described in "Materials and Methods". Using these antigens, significant antibody rises to LP were found in 8 of 20 serum pairs taken from volunteers who had colds induced by the $229 \mathrm{E}$ or LP viruses. As with neutralizing antibody rises, infection with either of these viruses produced a rise in complement-fixing antibody to both. Of 18 serum pairs taken from volunteers infected with $229 \mathrm{E}$ or LP viruses, none had rising $\mathrm{CF}$ titres to OC43, but 4 pairs showed rises to $\mathrm{MHV}_{3}$.

Hyperimmune ascitic fluids produced against those coronaviruses which could be grown only in human tissue culture cells contained anti-human activity. How- 
ever, these hyperimmune ascitic fluids had at least 4-fold higher titres against antigens prepared from infected L132 cells than against uninfected tissue culture antigens. Ascitic fluids and antisera prepared in mice using infected mouse brain inocula (for the $\mathrm{AIB}, \mathrm{MHV}_{3}$ and $\mathrm{OC} 43$ viruses) did not fix complement, at dilutions of 1/10 or greater, with normal mouse brain or with uninfected L 132 cell antigens.

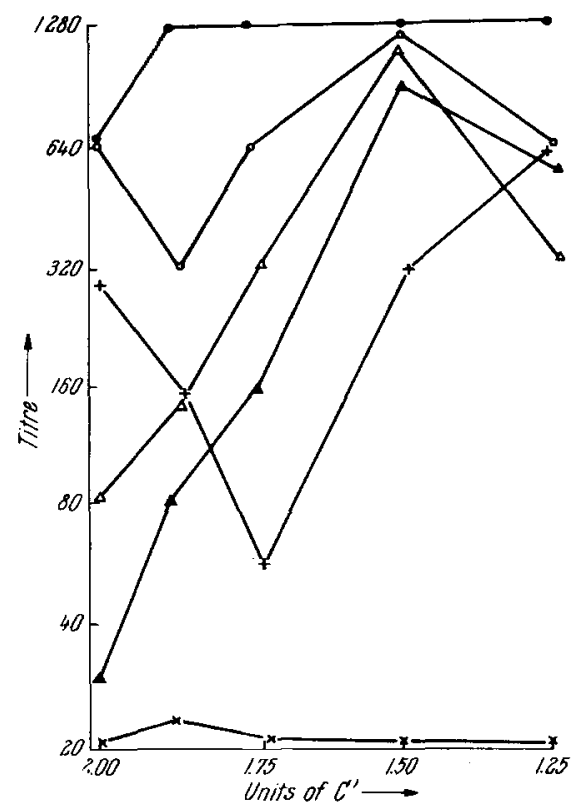

Fig. 2. The effect of the dose of complement (as $100 \%$ haemolytic units) on the reaction of coronavirus antisera with an MHV, mouse-brain antigen

$\begin{array}{lll}\begin{array}{l}\text { Ascites of serum } \\ \text { against }\end{array} & \text { Animal } & \text { Resulting from } \\ \text { MHV } & \text { Mouse } & \text { Hyperimmunization } \\ \text { MHV }_{3} & \text { Mouse } & \text { Experimental infection } \\ \text { MHV } & \text { Mouse } & \text { Experimental infection } \\ 229 \mathrm{E} & \text { Mouse } & \text { Hyperimmunization } \\ \text { Normal mouse brain } & \text { Mouse } & \text { Hyperimmunization } \\ \text { LP } & \text { Human } & \text { Experimental infection }\end{array}$

Chequer-board complement fixation tests were performed on the same day; all the hyperimmune sera were set up against all the antigens and several crossreactions were revealed. These are shown in Table 4. Chequer-board titrations were necessary because prozones occurred when high-titre sera were tested. These reactions were reproduced in repeated tests, but the titres obtained were not identical.

Homologous mixtures usually fixed complement well, but heterologous reactions often used less than 1 unit of complement; that is " $4+$ fixation" was never observed.

Antisera to LP, $229 \mathrm{E}$ and B 814 viruses fixed complement with $\mathrm{OC} 43$ antigens, and antiserum to the $\mathrm{OC43}$ virus fixed complement with antigens from these 
viruses. The $\mathrm{MHV}_{3}$ virus also showed reciprocal cross-reaction with $229 \mathrm{E}$, LP and OC43 viruses using the hyperimmune ascites, and the $\mathrm{MHV}_{3}$ antigen also fixed complement with the B 814 ascitic fluid.

\subsection{Gel-diffusion Tests}

Precipitin lines were detected with human sera and coronavirus antigens prepared from tissue cultures only when the latter were concentrated 10 - to 20 . fold. When such antigens were reacted with convalescent sera from volunteers who had been given $229 \mathrm{E}$ virus, 2 precipitin lines against the $229 \mathrm{E}$ and LP antigens were regularly seen. These lines were fully developed after about 48 hours and there were reactions of identity between the lines produced by the two antigens. However, sera taken from volunteers after infections with LP virus produced

Table 4. Cross Reactions between Coronaviruses Detected by Complement Fixation

\begin{tabular}{|c|c|c|c|c|c|c|c|c|}
\hline \multirow[t]{2}{*}{ Mouse asoites against } & \multicolumn{4}{|c|}{ Antigens (produced in L 132 cells) } & \multicolumn{4}{|c|}{ Antigens (produced in mice) } \\
\hline & $229 \mathrm{E}$ & $\mathbf{L P}$ & B 814 & $\begin{array}{l}\text { Normal } \\
\text { L } 132\end{array}$ & $\mathrm{OC} 43$ & $\mathrm{MHV}_{3}$ & AIB & $\begin{array}{l}\text { Normal } \\
\text { brain }\end{array}$ \\
\hline $229 \mathrm{E}^{1}$ & 640 & NR & NR & 60 & 40 & 40 & $<10$ & $<10$ \\
\hline $\mathrm{LP}$ & NR & 1280 & $\mathrm{NR}$ & 640 & 40 & 15 & $<10$ & $<10$ \\
\hline B 814 & NR & NR & 640 & 60 & 30 & $15<$ & $<10$ & $<10$ \\
\hline $\mathrm{OC} 43$ & 20 & 40 & 60 & $<10$ & 1280 & 40 & $<10$ & $<10$ \\
\hline $\mathrm{MHV}_{3}$ & 80 & 20 & 30 & $<10$ & 20 & 640 & 10 & $<\mathrm{IO}$ \\
\hline AIB & $<10$ & $<10$ & $<10$ & $<\mathrm{I0}$ & $<10$ & $<10$ & 60 & $<10$ \\
\hline Normal mouse serum & $<10$ & $<10$ & $<10$ & $<10$ & $<10$ & $<10$ & $<10$ & $<10$ \\
\hline
\end{tabular}

The reciprocals of titres obtained in complement fixation tests using hyperimmune mouse ascitic fluids and various coronavirus antisera. In all tests $1.5-1.75$ units of complement were used, and $3-6$ units of antigen.

I Ascites produced by inoculating mice with virus grown in L132 cells; therefore anti-human reactions may be involved in the complement fixation with antigens produced in these cells. $\mathrm{NR}=$ results not reliable because of anti-tissue reactions.

3 lines of precipitation with LP antigens, two of which were identical with lines produced with $229 \mathrm{E}$ antigens. The third line, produced against the LP and not $229 \mathrm{E}$ antigens was, like the others, seldom produced by volunteer sera taken prior to infection, but was occasionally produced by convalescent sera taken after a $229 \mathrm{E}$ virus infection. The B814 virus antigen seldom produced lines of precipitation with human sera, even with convalescent sera from volunteers who developed severe colds after inoculation with this virus. In the reactions that were observed, only single lines were detected.

The results with animal antisera to $229 \mathrm{E}, \mathrm{LP}$ and $\mathrm{B} 814$ viruses and their homologous antigens were not amenable to a reliable interpretation because of the profusion of anti-tissue lines which appeared. On the other hand, hyperimmune virus-specific mouse ascites produced against AIB (1 serum), $\mathrm{MHV}_{3}$ (3 sera) and OC43 (3 sera) gave clear lines in the homologous reactions, as seen in Fig. 3. Using these sera, the cross-reactions observed by neutralization and complement fixation tests were corroborated. It is interesting to note that very few of the heterologous lines produced showed reactions of identity with homolog- 


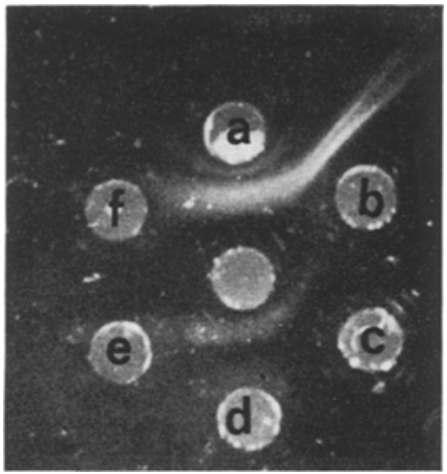

Fig. 3 a

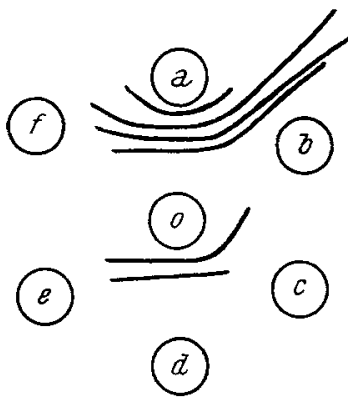

Fig. $3 \mathrm{~b}$

Fig. 3. Results of an immunodiffusion test with coronavirus antigens and hyperimmune mouse aseitic fluids.

Well $\mathbf{b}$ - ascitic fluid produced by hyperimmunising adult mice with ether-treated oC43 antigen.

0 - ascitic fluid produced in mice after recovery from an infection with 0043 virus.

f - control ascitic fluid.

a - OC43 mouse-brain antigen.

c - normal $\mathbf{L} 132$ cell antigen

d - LP antigen produced in L 132 cells.

e - normal mouse brain antigen.

The line drawing is a representation of the lines seen on the original immunodiffusion plate; not all these lines are visible or separately resolved in the photograph

Table 5. Cross-reactions Detected between Coronaviruses by Immunodiffusion. The Numbers of Precipitin Lines Obtained in the Reastions between Various Coronavirus Antigens and Antisera

\begin{tabular}{|c|c|c|c|c|c|c|}
\hline \multirow[t]{2}{*}{ Serum or ascites } & \multicolumn{6}{|c|}{ Antigens } \\
\hline & $229 \mathrm{E}$ & LP & B 814 & $\mathrm{OC} 43$ & $\mathrm{MHV}_{3}$ & AIB \\
\hline Hyperimmune $229 \mathrm{E}$ & - & - & -- & 0 & 1 & 0 \\
\hline Human after $229 \mathrm{E}$ & $\begin{array}{l}2 \\
\text { (show }\end{array}$ & 2 & 0 & 0 & 0 & 0 \\
\hline Hyperimmune LP & - & - & - & 2 & 1 & 0 \\
\hline Human after LP & $\begin{array}{l}2 \\
\text { (show }\end{array}$ & $\begin{array}{l}3 \\
\text { entity) }\end{array}$ & 0 & 0 & 0 & 0 \\
\hline Hyperimmune B 814 & - & - & 1 & 0 & 0 & 0 \\
\hline Human after B 814 & 0 & 0 & 1 & 0 & 0 & 0 \\
\hline $\begin{array}{l}\text { Hyperimmune OC43 } \\
\text { (specific) }\end{array}$ & 0 & 1 & 0 & 4 & 0 & 0 \\
\hline $\begin{array}{l}\text { Hyperimmune } \mathrm{MHV}_{3} \\
\text { (specific) }\end{array}$ & 1 & 0 & 0 & 0 & 2 & 0 \\
\hline $\begin{array}{l}\text { Hyperimmune AIB } \\
\text { (specific) }\end{array}$ & 0 & 0 & 0 & 0 & 0 & 2 \\
\hline
\end{tabular}

- = not included because of the presence of strong lines against tissue culture components. Except where indicated, reactions of complete or partial identity were not observed. 
ous lines for the same virus. The reasons for this are not known; however, the lines were not produced against control antigens, or with control sera.

A summary of the immuno-diffusion results is seen in Table 5. Precipitin lines were observed with some human sera against strong OC43 mouse-brain antigens, but human sera were never shown to react with $\mathrm{MHV}_{3}$ or AIB antigens. This may reflect the fact that comparatively weak antigens were made with these two viruses and that they gave only two precipitin lines against the homologous hyperimmune sera, although three precipitin lines were obtained with AIB by TeveTHIA and Cunningham (1968).

Table 6. Summary of Antigenic Cross-reactions amongst Coronaviruses

\begin{tabular}{|c|c|c|c|c|c|c|}
\hline Virus or antigen: & $229 \mathrm{E}$ & LP & B 814 & $\mathrm{OC} 43$ & $\mathrm{MHV}_{3}$ & AIB \\
\hline \multicolumn{7}{|l|}{ Sera against: } \\
\hline $229 \mathrm{E}$ & $\mathrm{H}$ & $\stackrel{+}{(\mathrm{n}, \mathrm{e}, \mathrm{g})}$ & - & - & $\begin{array}{l}+ \\
(c, g)\end{array}$ & - \\
\hline LP & $\stackrel{+}{(\mathrm{n}, \mathrm{e}, \mathrm{g})}$ & $\mathrm{H}$ & - & - & - & - \\
\hline В 814 & - & - & $\mathrm{H}$ & - & $\frac{+}{(c)}$ & - \\
\hline $\mathrm{OC} 43$ & $\begin{array}{l}+ \\
(\mathrm{n}, \mathrm{c})\end{array}$ & $\begin{array}{l}+ \\
(\mathrm{c}, \mathrm{g})\end{array}$ & - & $\mathbf{H}$ & $\begin{array}{l}+ \\
\text { (c) }\end{array}$ & - \\
\hline $\mathrm{MHV}_{3}$ & $\begin{array}{l}+ \\
(c, g)\end{array}$ & $\begin{array}{l}+ \\
(\mathrm{c}, \mathrm{g})\end{array}$ & - & $\begin{array}{l}+ \\
(\mathbf{c})\end{array}$ & $\mathrm{H}$ & 一 \\
\hline AIB & - & - & - & - & - & $\mathbf{H}$ \\
\hline
\end{tabular}

$\mathrm{H}=$ homologous reaction, $\mathrm{n}=$ neutralization, $\mathrm{c}=$ complement fixation, $g=$ gel-diffusion.

\section{Discussion}

These studies have demonstrated that viruses which were grouped together as "coronaviruses" because they were morphologically similar show several serological similarities as well. A summary of the cross-reactions detected in these studies is shown in Table 6. The cross-reactions found have not revealed common or group antigens as are found with the influenza viruses, but rather haphazard inter-relationships like those found between the different parainfluenza viruses, mumps and Newcastle disease virus. As might be expected, the less specific serological tests of immuno-diffusion and complement fixation produced more evidence of cross-reaction than did neutralization and $\mathrm{HI}$ tests.

Some of these results confirm other studies on antigenic relationships amongst coronaviruses (McIntosh et al., 1969; Kaye and Dowdle, 1969) particularly in that avian infectious bronchitis virus does not seem to be related to the others by any of the tests used.

The viruses tested here showed some anomalies in their neutralization by antisera. Neutralization of a virus may involve several immunological reactions and not enough is known about the neutralization of coronaviruses. Complement or fresh rabbit serum will enhance the neutralization of, for example, rubella (NEVA and WELLER, 1964) and respiratory syncytial virus (STотT et al., 1967); nevertheless 
the human coronaviruses were not neutralized by antiviral antisera to any greater degree when complement was added to the system. This contrasts with the neutralization of avian infectious bronchitis virus in which complement increases the neutralization index of some sera by up to three orders of magnitude (BERRY and ALmeIdA, 1968). This virus is also neutralized by anti-host cell antisera which in the presence of complement (unheated guinea-pig serum) produce $80 \AA$ holes in the virus envelope. These holes are also produced by heterotypic (rabbit) but not by homotypic (chicken) antisera. Anti-human antisera did not produce any significant neutralization of either the $229 \mathrm{E}$ or LP viruses and complement holes are produced in the envelope of $229 \mathrm{E}$ virus by both homotypic and heterotypic (human) antisera (Almeida and Bradburne, unpublished data). This suggests that these two viruses differ somewhat in assembly from infectious bronchitis virus, though such differences have not been detected in electron-microscopic studies by other workers (BECKER et al., 1967). This could be due, amongst other things, to differences in surface structure or in susceptibility to complement enzymes.

The complement fixation and haemagglutination-inhibition results suggest that MHV possesses several antigens which it shares with one or other of the human strains. This work shows that the $229 \mathrm{E}$ and LP viruses are closely related but distinguishable serologically and that they cross-react with $\mathrm{MHV}_{3}$; also OC43 antisera can neutralize $229 \mathrm{E}$. This does not support the suggestion by McInTosh et al. (1969) that 229 E-like viruses form one uniform group serologically, and that the $0 \mathrm{C} 43-38$ group are a more heterogeneous collection, being serologically distinct from $229 \mathrm{E}$ and characterized by their cross-reactions with MHV strains.

The use of human sera in coronavirus serology has been shown to be of only limited value in differentiating between infections of the various human coronaviruses because of the heterologous rises which can be found in these sera. A specific antibody response probably only occurs on the first exposure to a member of the coronavirus group, and there is evidence that this response is poor, and may be boosted by later immunological stimulation.

Of the two animal coronaviruses, infectious bronchitis virus seems to be antigenically far more distant from the human coronaviruses than mouse hepatitis virus $\left(\mathrm{MHV}_{3}\right)$. This fits well with the observations of HARTLEY et al. (1964) that human sera contain antibody to MHV which may rise during an infection, while MrLLER and YATES (1968) detected no antibody, in human sera, to infectious bronchitis virus except in persons who were in contact with poultry.

Studies on the antigenic structure of the coronaviruses are continuing so that the antigens responsible for these cross-reactions may be isolated.

\section{Acknowledgements}

The author gratefully acknowledges the invaluable technical assistance given by Miss B. A. Somerset and the inspiration and assistance in preparing the manuscript given by Dr. D. A. J. Tyrrell.

\section{References}

1. Becker, W. B., K. McIntosh, J. H. Dees, and R. M. Chanock: Morphogenesis of avian infectious bronchitis and a related human virus (strain $229 \mathrm{E}$ ). J. Virol. 1,1019 (1967). 
2. Berry, D. M., and June D. Almeida: The morphological and biological effects of various antisera on avian infectious bronchitis virus. J. gen. Virol. 3, 97 (1968).

3. Berry, D. M., J. G. Cruickshank, H. P. Chu, and R. J. H. Wells: The structure of infectious bronchitis virus. Virology 23, 403 (1964).

4. Bradburne, A. F.: Sensitivity of L 132 cells to some "new" respiratory viruses. Nature (Lond.) 221, 85 (1969).

5. Bradburne, A. F., and D. A. J. TyrRell: The propagation of "coronaviruses" in tissue-culture. Arch. ges. Virusforsch. 28, 133 (1969).

6. Davis, E. V.: Fed. Proc. 19, 386 (1960).

7. Estola, T.: Studies on the infectious bronchitis virus of chickens isolated in Finland. Acta vet. scand. Suppl. 18 (1966).

8. GLeDHILL, A. W.: In: Virus Diseases of Laboratory Animals. London and New York: Academic Press, 1961.

9. HAMre, D., and J. J. Procknow: A new virus isolated from the human respiratory tract. Proc. Soc. exp. Biol. (N.Y.) 121, 190 (1966).

10. Hartley, Janet W., W. P. Rowe, H. Bloom, and H. C. Turner: Antibodies to mouse hepatitis viruses in human sera. Proc. Soc. exp. Biol. (N.Y.) 115, 414 (1964).

11. KAYE, H. S., and W. R. DowDLE: Some characteristics of haemagglutination of certain strains of "IBV-like" viruses. J. infect. Dis. 120, 576 (1969).

12. MoIntosh, K., Jane H. Dees, W. B. Becker, A. Z. Kapikian, and R. M. ChaNocK: Recovery in tracheal organ cultures of novel viruses from patients with respiratory disease. Proc. nat. Acad. Sci. (Wash.) 57, 933 (1967a).

13. McIntosh, K., W. B. Becker, and R. M. Chanock: Growth in suckling mouse brain of "IBV-like" viruses from patients with upper respiratory tract disease. Proc. nat. Acad. Sei. (Wash.) 58, 2268 (1967 b).

14. McIntosh, K., A. Z. Kapikian, Kathleen A. Harrison, Janet W. Hartley, and R. M. CHANOCK: Antigenic relationships among the coronaviruses of men and between human and animal coronaviruses. J. Immunol. 102, 1109 (1969).

15. Miller, L. T., and V. J. YATES: Neutralization of infectious bronchitis virus by human sera. Amer. J. Epidem. 88, 406 (1968).

16. NATURE (Lond.): "Coronaviruses". 220, 650 (1968).

17. Neva, F. A., and T. H. WeLLAR: Rubella interferon and factors influencing the indirect neutralization test for Rubella antibody. J. Immunol. 93, 466 (1964).

18. Reed, L. J., and H. MUEnch: A simple method of estimating fifty per cent endpoints. Amer. J. Hyg. 27, 493 (1938).

19. Sever, J. L.: Application of a mierotechnique to viral serological investigations. J. Immunol. 88, 320 (1962).

20. Sommerville, R. G.: The production of fluorescent antibody reagents for virus diagnosis in the albino mouse: 1. Hyperimmune anti-species serum. Arch. ges. Virusforsch. 20, 445 (1967).

21. Stotr, E. J., E. J. Bell, M. B. Eadie, C. A. C. Ross, and N. R. Grist: A comparative virological study of children in hospital with respiratory and diarrhoeal illness. J. Hyg. (Lond.) 65, 9 (1967).

22. Tevethia, S. S., and C. H. Cunningham: Antigenic characterization of infectious bronchitis virus. J. Immunol. 100, 793 (1968).

23. Trrkeld, D. A. J., and June D. Almeida: Direct electronmicroseopy of organ cultures for the detection and characterization of viruses. Arch. ges. Virusforsch. 22, 417 (1967).

24. TYrReLL, D. A. J., and M. L. BYNOE : Cultivation of a novel type of common cold virus in organ cultures. Brit. med. J. 1, 1467 (1965).

25. Trrrell, D. A. J., M. L. Bynoe, and B. HoorN : Cultivation of "difficult" viruses from patients with common colds. Brit. med. J. 1, 606 (1968).

Author's address: Mr. A. F. Bradburne, MRC Common Cold Unit, Harvard Hospital, Coombe Road, Salisbury, Wilts., England. 